\title{
Embryonic and fetal development in different genotypes in pigs
}

\author{
S. P. Ford \\ Department of Animal Science, Iowa State University, Ames, IA 50011-3150, USA
}

\begin{abstract}
It is widely accepted that uterine capacity, not ovulation rate, is the greatest restraint on litter size in pigs. Recently, the reproductive strategy(s) of the Chinese Meishan pig, a breed which farrows three to five more piglets per litter than US or European pig breeds, has come under intense scrutiny. It was initially determined that the Meishan female could farrow more viable piglets per litter than US or European pig breeds, with a uterine size and ovulation rate equivalent to those of less prolific breeds. It has become apparent that the Meishan conceptus exhibits a reduced trophectoderm mitotic rate during the preimplantation period, elongates from fewer cells and remains smaller throughout gestation compared with conceptuses from less prolific US or European pig breeds. This strategy by the Meishan conceptus for a lower growth rate results in a marked reduction in conceptus loss through day 18 of gestation compared with less prolific breeds. An additional strategy is required in the Meishan to allow the larger number of viable fetuses to survive after day 30 of gestation when uterine capacity becomes limiting. Our research has demonstrated that the rapid growth of the fetus in US pig breeds appears to require continued placental growth to increase the surface area for nutrient exchange. In contrast, the increased numbers of smaller Meishan fetuses achieve the same increase in placental efficiency by markedly increasing the density of placental blood vessels at the fetal-maternal interface. This proliferation of placental blood vessels obviates the need for marked increases in placental size.
\end{abstract}

\section{Introduction}

Evidence has rapidly accumulated suggesting that from the time a conceptus enters the uterus, it is subject to modulations of growth, differentiation or both processes through its exposure to a bewildering array of uterine environmental factors (Paria and Dey, 1990; Pollard, 1990; Simmen and Simmen, 1991; Simmen et al., 1995). Furthermore, far from being passive in this process, all evidence points to the fact that both the conceptus and the uterus actively contribute to placental and fetal growth and development throughout gestation in a variety of mammalian species (Venge, 1950; Hunter, 1958; Ferrell, 1991a,b; Youngs et al., 1994).

In this review, I will emphasize the two periods during gestation in the pig that I consider are the most important in determining the number of viable piglets at farrowing. These periods include the peri-implantation period (i.e. days 12-18), and the period from midgestation to term. It is during the peri-implantation period that the greatest numbers of viable conceptuses in a litter are lost (about $75 \%$ of the total loss; reviewed by Ford and Youngs, 1993). Fetal weight increases most markedly during the latter half of gestation in pigs, as in other mammalian species, in association with very limited placental growth (Warwick, 1928; Reynolds and Redmer, 1995). Furthermore, on the basis of a number of studies, increased blood flow at the fetal-maternal interface appears to be a primary determinant of increased transplacental exchange during this period of late gestation in livestock species (Ford, 1995; Reynolds and Redmer, 1995). Reynolds $e$ al. (1985) demonstrated that in pigs as the number of fetuses in a uterine horn increased (range from two to eight fetuses), the blood flow allotted to each during late gestation progressively declined. Furthermore, as uterine blood flow per 
Table 1. Comparisons between breeds in ovulation status and early conceptus development $48-54 \mathrm{~h}$ after the onset of oestrus

\begin{tabular}{lcc}
\hline Parameter & Meishan $(n=66)$ & Yorkshire $(n=55)$ \\
\hline Ovulation status (\% of gilts) & & \\
All follicles ovulated & $89.4 \%$ & $92.7 \%$ \\
Some but not all follicles ovulated & $7.6 \%$ & $5.5 \%$ \\
No follicles ovulated & $3.0 \%$ & $1.8 \%$ \\
Conceptus development & & \\
Minimum number of cells & $1.5 \pm 0.9$ & $1.9 \pm 0.3$ \\
Maximum number of cells & & $3.3 \pm 0.4$ \\
Range of cell numbers across all conceptuses & $1.4 \pm 0.4$ & $1-8$ \\
\hline
\end{tabular}

-Average cell number of the least developed conceptus in a litter. 'Average cell number of the most developed conceptus in a litter. $n=$ number of litters.

fetus declined with increasing numbers of fetuses, umbilical blood flow to these fetuses also declined $(r=0.70 ; P<0.01)$. The decrease in placental surface area of each conceptus with increasing numbers of fetuses per horn (Knight et al., 1977) may reduce the size of each placental vascular bed, with concomitant reductions in fetal growth.

However, these periods are by no means independent, since the number of conceptuses surviving the peri-implantation period will dictate the uterine space that can be allotted to each for the remainder of gestation. Thus, it is assumed that prolific pig breeds such as the Chinese Meishan, which exhibits a markedly reduced preimplantation conceptus loss when compared with commercial US and European pig breeds (Galvin et al., 1993; Haley and Lee, 1993), must have a strategy for successfully maintaining these larger litters to term. This is difficult to explain as the size of the uterus in Meishan and US and European pig breeds is similar when adjusted for the slaughter weight of the female (Bazer et al., 1988; Lee et al., 1995).

For the past 20 years, the litter size of commercial pig breeds in the US has been relatively constant, despite repeated attempts to define selection criteria for an increased number of piglets (Pork Facts, 1993). This failure to change litter size significantly was the major impetus for the importation of the prolific Meishan pig into the US from China in 1989. The Meishan is known to farrow three to five more viable piglets per litter than US or European pig breeds (In et al., 1992). This review will emphasize the most recent information obtained by our group and others from studies in Meishan pigs and provide insight into its prolificacy.

\section{The Peri-implantation Period}

An essential period for the establishment of pregnancy in the pig occurs between day 12 and day 18 after mating. During this period, conceptuses expand to 8-10 $\mathrm{mm}$ spheres, space themselves uniformly throughout the uterus (Dhindsa et al., 1967; Dziuk, 1968, 1985), elongate to long filamentous forms (Geisert et al., 1982a), and attach to the uterine wall through interdigitation of trophoblastic and endometrial microvilli (Dantzer, 1985).

Coincident with expansion and elongation, the day 11-12 conceptuses acquire the ability to synthesize oestradiol (Gadsby et al., 1980; Pusateri et al., 1990). Oestradiol is measurable in large spherical blastocysts, and then increases rapidly during tubular expansion into filamentous forms, before declining precipitously after elongation (Pusateri et al., 1990). On days 11-12 after mating, the progesterone-primed endometrium is very sensitive to conceptus oestradiol, which will alter stromal and epithelial development (Geisert $e$ t al., 1991) and secretory activity (Geisert $e$ t al., 1982b; Morgan et al., 1987). During the late preimplantation period, blastocysts are especially dependent 
Table 2. Comparisons between breeds of ovulation rate, conceptus recovery on days 11 to 12 of gestation and litter size

\begin{tabular}{lllll}
\hline Parameter & Meishan & $(n)$ & Yorkshire & $(n)$ \\
\hline Ovulation rate $^{\mathrm{a}}$ & $16.5 \pm 0.5$ & $(70)$ & $16.3 \pm 0.4$ & $(93)$ \\
Number of conceptuses collected $^{\natural}$ & $12.5 \pm 0.5$ & $(69)$ & $12.3 \pm 0.5$ & $(82)$ \\
Litter size $^{b}$ & $12.3 \pm 0.4$ & $(42)$ & $8.9 \pm 0.4$ & $(66)$ \\
\hline
\end{tabular}

- Means \pm SEM are not different between breeds, $P>0.30$.

Calculated from another group of gilts of similar reproductive age. Means \pm SEM are significantly different,

$P<0.01$.

$n=$ number of litters.

upon endometrial secretion of specific hormones, growth factors and nutrients for normal growth and development (Roberts and Bazer, 1988). Owing to the marked variation among littermates in conceptus size at this time of gestation, the most advanced conceptuses in the litter begin the synthesis of oestradiol before other conceptuses (Stroband and Van der Lende, 1990). The increase in uterine luminal oestradiol results in increased uterine blood flow and vascular permeability, and alters the amount and composition of endometrial secretions to provide a suitable microenvironment for the increasingly complex requirements of the conceptus (Flint, 1981; Ford et al., 1982; Van der Meulen et al., 1989; Stroband and Van der Lende, 1990). The less well-developed conceptuses in the litter are thus exposed to this rapidly changing uterine environment, resulting in their eventual demise (Dziuk, 1987; Pope et al., 1990; Pope, 1994).

The high incidence of preimplantation conceptus loss in US and European pig breeds was first noted by Hammond (1914), and has since been confirmed to average approximately $30 \%$ (Dziuk, 1987). The period surrounding implantation is considered especially critical for conceptus survival, and most loss occurs between days 12 and 18 after mating (Scofield, 1972).

Uterine capacity has been defined as the maximum number of fetuses that can be successfully carried to term when the number of potentially viable conceptuses is not limiting (Christenson $e t$ al., 1987). Treatments imposed to exceed uterine capacity in pigs (for example superovulation, superinduction) will produce large numbers of viable conceptuses, but only to approximately day 30 of gestation (Dziuk, 1968; Pope et al., 1972). Thereafter, the effect(s) of the limiting uterine capacity is evident, in that these females will give birth to numbers of piglets equivalent to those found in untreated pigs.

\section{Meishan versus Yorkshire conceptuses during the preimplantation period}

If a large number of Meishan and Yorkshire gilts in our herds were compared at the same reproductive age (i.e. two to five post-pubertal oestrous cycles), no obvious differences among breeds were observed in the interval from the initiation of oestrus to ovulation or the conceptus stages recovered on day 2 (Table 1). Furthermore, ovulation rate and the number of viable conceptuses recovered on day 12 are almost identical, even though these Meishan gilts farrow approximately three more piglets than do the Yorkshire gilts (Table 2). We have used Meishan and Yorkshire gilts of these equivalent reproductive ages for our studies on the control of litter size. This is critical, since ovulation rate increases progressively to reach 30 to 40 ova shed in older multiparous Meishan sows, while remaining at 14 to 16 in US and European pig breeds (Christenson, 1993).

In our herds, Meishan and Yorkshire conceptuses elongate synchronously on days 11-12 after mating (Fig. 1), a time similar to that reported for other US and European pig breeds (Youngs $e t$ al., 1994). A similar range of conceptus development occurs in both breeds throughout this period (Fig. 1). The apparent greater absolute diversity within the Yorkshire litters is accounted for by a similar within-litter variation (standard deviation) in litters with an increased mean conceptus diameter. However, if the within-litter coefficient of variation, which takes into consideration the difference in 


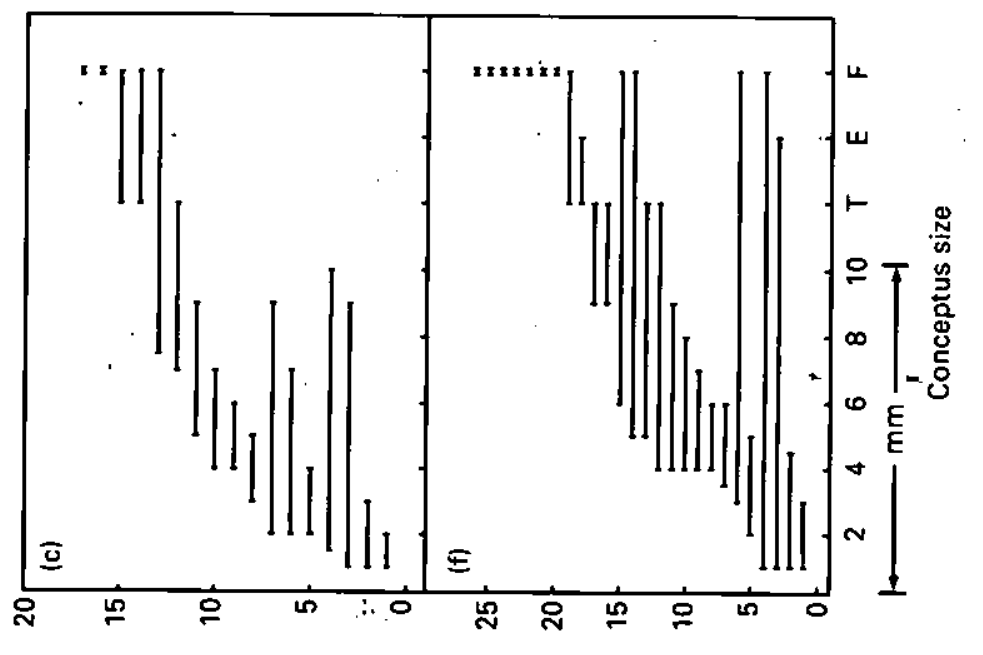


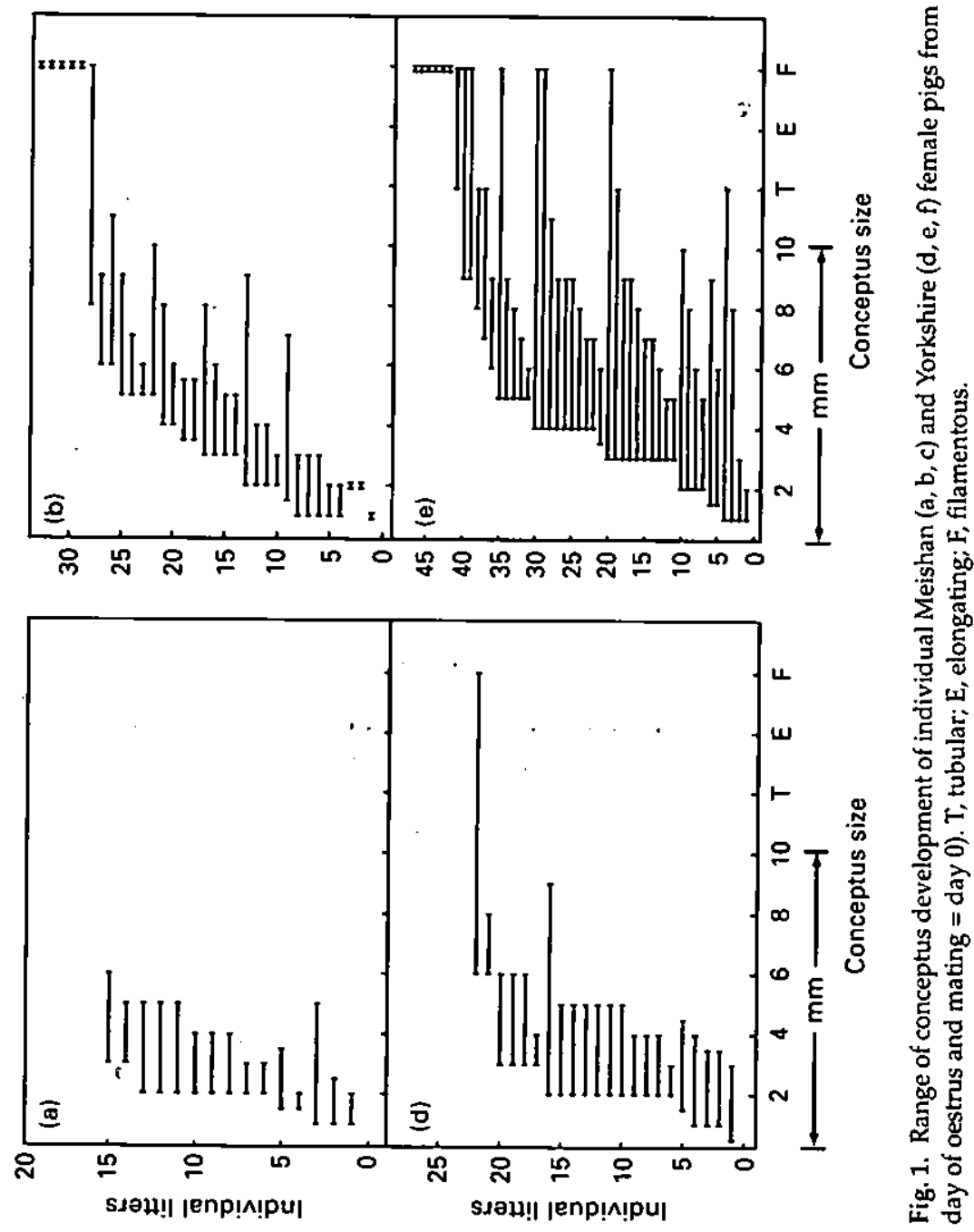


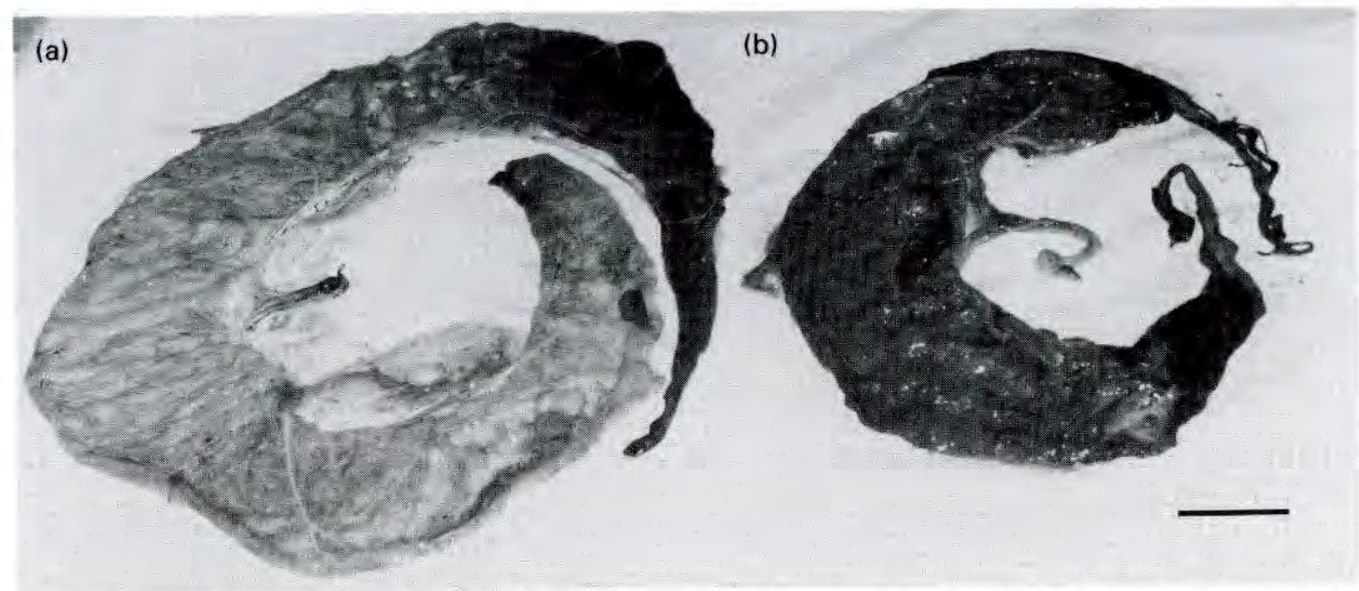

Fig. 2. A large relatively avascular Yorkshire placenta (a) and a small highly vascular Meishan placenta (b) recovered from a single Yorkshire recipient female pig. These placentae were matched to fetuses of very similar birth weight. Scale bar represents $10 \mathrm{~cm}$.

mean conceptus diameter, is calculated, there are breed differences (i.e. differences in Yorkshire litters are greater than Meishan litters). Thus, although the average within-litter diversity is relatively constant across breeds, the absolute diversity in a litter is associated with the degree of conceptus development in that litter. These data are consistent with the published reports that Meishan conceptuses at days 11-12 are smaller when they initiate steroidogenesis (Wilson and Ford, 1997) and elongate (Youngs et al., 1994) than Yorkshire conceptuses. Furthermore, Wilson et al. (1995) reported that Meishan filamentous conceptuses were shorter and contained fewer cells than Yorkshire conceptuses on day 14.

The smaller size of the Meishan versus the Yorkshire preimplantation conceptus results from its markedly small numbers of trophectoderm (TE) cells from day 5 (Rivera et al., 1996) to day 12 (Wilson and Ford, 1997) in similar stage conceptuses. Furthermore, the reduction in numbers of TE cells in Meishan versus Yorkshire conceptuses has been shown to result from a lower mitotic rate of these cells in the Meishan conceptus (Wilson and Ford, 1997). Conley et al. (1992) have shown that P450 17 $\alpha$-hydroxylase/17-20 lyase is the enzyme most closely associated with pig conceptus oestradiol production, and have localized this enzyme exclusively in the TE (Conley et al., 1994). In association with its reduced population of TE cells on days 11-12, Meishan conceptuses produce and secrete less oestradiol into uterine luminal fluid than do similar stage Yorkshire conceptuses (Wilson and Ford, 1997). Furthermore, these researchers demonstrated that the decreased oestradiol concentrations in uterine luminal fluid of Meishan versus Yorkshire females is associated $(r=0.57$; $P<0.001$ ) with a lower concentration of insulin-like growth factor-I (IGF-I) in the same flushings.

The potential interrelationship between uterine luminal oestradiol and IGF-I may be crucial for the further rapid growth and development of the conceptus as it prepares to undergo elongation. Evidence supporting this hypothesis includes: (1) the presence of receptors for IGF-I on the preimplantation pig conceptus (Corps et al., 1990), (2) the finding that insulin, a hormone known to bind the IGF-I receptor, increases protein synthesis by, and the growth of, the preimplantation pig conceptus (Lewis et al., 1992) and (3) the expression of steroidogenic enzymes important for oestradiol biosynthesis has been correlated with the concentration of IGF-I in uterine luminal fluid (Ko et al., 1994). These and other findings have led Simmen et al. (1995) to propose a feed forward mechanism in which the oestradiol produced by the rapidly expanding pig blastocyst stimulates endometrial IGF-I production which, in turn, stimulates conceptus steroidogenic enzymes and further oestradiol synthesis. However, this story is far from complete, as Chastant et al. (1994) failed to detect IGF-I receptors on pig conceptuses from day 4 to day 10 of gestation, or on TE cells from the placenta on day 20 . These data suggest that the reduced size and oestradiol secretory activity of the 


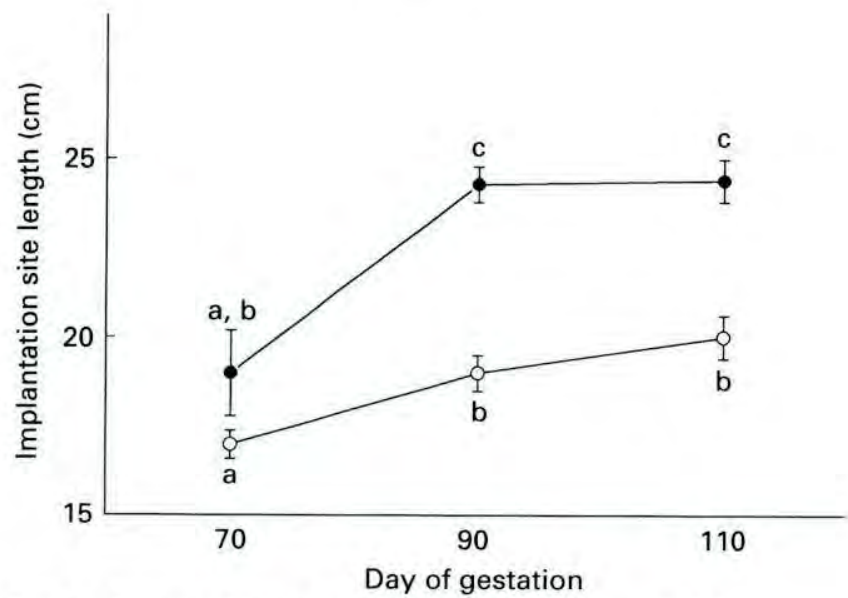

Fig. 3. Average length of the uterine horn occupied by each conceptus on days 70,90 and 110 of gestation in $(O)$ Meishan and (O) Yorkshire female pigs. ${ }^{a} b, c$ Means \pm SEM with different superscripts are significantly different $(P<0.01)$.

Meishan conceptus, when compared with Yorkshire conceptuses throughout blastocyst expansion and elongation, may allow for greater conceptus survival and potential litter size.

Finally, a reciprocal conceptus transfer experiment between Meishan and Yorkshire females was conducted to evaluate the specific influences of uterine environment versus conceptus genotype on preimplantation conceptus growth rate (Youngs et al., 1994). In this study, conceptuses were transferred from Meishan or Yorkshire donors to synchronous recipients of either breed on day 2 and removed on day 12 of gestation. Meishan conceptuses were always smaller than Yorkshire conceptuses at a similar stage on day 12 , regardless of uterine environment, but conceptuses of both breeds contained fewer cells and were smaller when recovered from a Meishan uterus than when recovered from a Yorkshire uterus. Furthermore, conceptuses of both genotypes produced markedly less oestradiol when contained in a Meishan uterus than when contained in a Yorkshire uterus. These data suggest that both uterine environmental and conceptus genotype affect preimplantation conceptus growth, and that only uterine environmental differences affect oestradiol secretion. These data are consistent with the concept that the uterine environment (Meishan versus Yorkshire) is the sole determinant of conceptus oestradiol secretory activity.

\section{Latter Half of Gestation}

In pigs, it is generally accepted that placentae that are smaller than average size limit fetal growth (Knight et al., 1977). As the demands of the fetus for nutrients and oxygen increase markedly in late gestation, placental insufficiency should become most evident during this time. The pig placenta is diffuse according to the classification of Grosser (1909) and of the epitheliochorial type. Over the mouths of the uterine glands the allantochorionic membrane is not attached to the endometrial epithelium, but forms regular or irregular areolae which first appear on day 30 of gestation (Brambell, 1933). The interareolar placenta is composed of chorionic ridges and their corresponding endometrial folds. Placental efficiency is determined by its surface area of contact with the uterine wall (chorionic villus surface area) and the thickness of the placental membranes. Baur (1977) has shown that the chorionic villus surface area increases progressively throughout gestation in pigs, but lags behind fetal weight. However, there is clear histological evidence of a progressive thinning of the effective placental barrier separating the fetal and maternal bloodstream in pigs (Friess et al., 1980). This thinning, which accelerates during the last third of gestation, results from a marked 

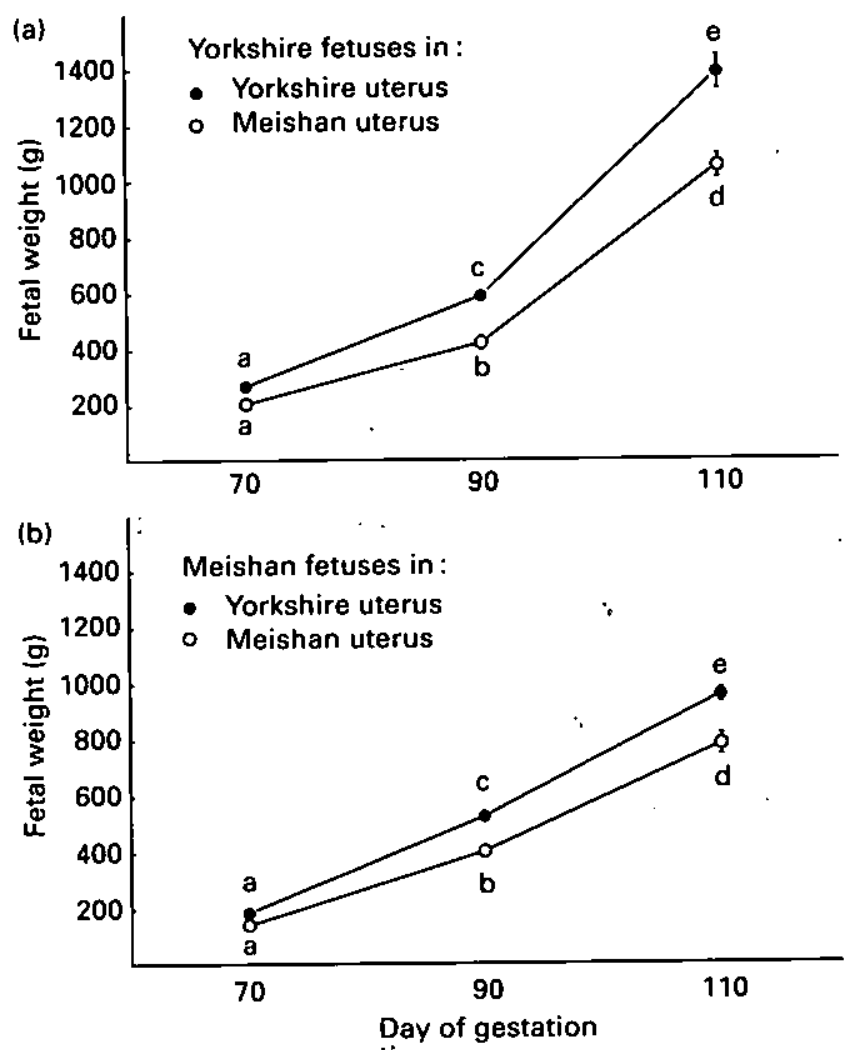

Fig. 4. Weight of (a) Yorkshire and (b) Meishan fetuses in Yorkshire and Meishan uteri on days 70,90 and 110 of gestation. $a, b, c, d, c$ Within a fetal breed, means \pm SEM with different superscripts are significantly different $(P<0.05)$.

indentation of fetal vessels into the trophoblast, and the indentation of maternal capillaries into the uterine epithelial cells at the fetal-maternal interface. At the end of pregnancy, the distance between fetal and maternal capillaries is often less than $2 \mu \mathrm{m}$.

\section{Meishan versus Yorkshire conceptuses during late gestation}

We next investigated the consequences of the observed differences in uterine environment and conceptus genotype on subsequent placental and fetal growth between Meishan and Yorkshire pigs. Rivera et al. (1994) transferred 20 conceptuses (ten Meishan plus ten Yorkshire) into the oviducts of synchronous Meishan or Yorkshire recipient females on day 2 after oestrus, and recovered the conceptuses on day 90 of gestation. More $(P<0.05)$ fetuses were recovered from Meishan recipients on day 90 than from Yorkshire recipients $(14.8 \pm 0.4$ versus $10.0 \pm 1.9$ fetuses, respectively). Placental weight was markedly reduced for conceptuses recovered from Meishan versus Yorkshire recipient females, whereas fetal weight was affected both by recipient breed and by fetal genotype. Meishan and Yorkshire fetuses gestated in Meishan uteri to day 90 were similar in weight, averaging $381 \pm 23$ $\mathrm{g}$, but were markedly smaller than either Meishan $(498 \pm 20 \mathrm{~g})$ or Yorkshire $(613 \pm 16 \mathrm{~g})$ fetuses gestated in Yorkshire uteri. Interestingly, day 90 Yorkshire fetuses were larger than Meishan fetuses when both were gestated in Yorkshire recipient females. These data suggest that the Meishan uterine environment restricts placental growth of both Meishan and Yorkshire conceptuses, ultimately limiting fetal growth by day 90 of gestation. It also appeared that the larger placental sizes of 


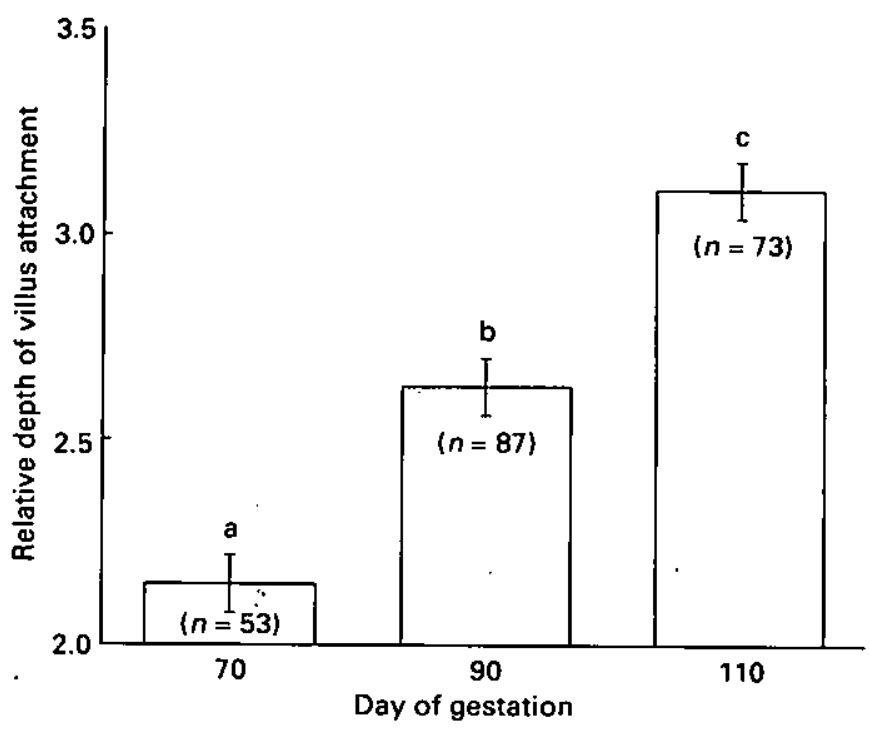

Fig. 5. The relative depth of villus attachment of placentae of Meishan versus Yorkshire pigs on days 70,90 and 110 of gestation. $a, b M e a n S \pm S E M$ with different superscripts are significantly different $(P<0.05)$.

Meishan and Yorkshire conceptuses in Yorkshire uteri allowed the expression of breed-specific differences in fetal growth.

Owing to this breed-specific (Meishan versus Yorkshire) difference in fetal weight of littermates gestated in Yorkshire recipients, a subsequent experiment was conducted with Yorkshire recipients only. As previously described, both Meishan $(n=10)$ and Yorkshire $(n=10)$ conceptuses were transferred to Yorkshire recipients on day 2, but instead of recovering conceptuses on day 90, the females were allowed to farrow. At farrowing, each piglet was caught as it appeared at the vaginal opening and the exposed umbilical cord was tagged to match the piglet's number, cut and allowed to retract. In this way, each piglet could be matched with the appropriate placenta at expulsion. Unexpectedly, two visually distinct placental types were observed during the farrowing of each recipient Yorkshire female. Relatively large and blanched placentae were exclusively matched to Yorkshire fetuses, while smaller, very reddened (i.e. more vascular) placentae were matched to Meishan fetuses. Two placentae expelled from a single Yorkshire recipient female and matched to a Yorkshire and a Meishan piglet of equal weight are shown in Fig. 2. In these mixed litters of Meishan and Yorkshire fetuses, the piglet weight $(\mathrm{g})$ : placental weight $(\mathrm{g})$ ratio was calculated as an estimate of placental efficiency for each conceptus. The piglet weight: placental weight ratio differed markedly $(P<0.05)$ for Meishan conceptuses, which averaged $8.7 \pm 0.4$ when compared with littermate Yorkshire conceptuses which averaged $3.4 \pm 0.8$. Interestingly, these breed differences in fetal weight: placental weight ratios are due predominately to differences in placental weight (approximately $66 \%$ ) rather than to any marked differences in piglet weight $(7 \%$ ).

Meishan and Yorkshire recipient females carrying either Meishan or Yorkshire fetuses were slaughtered on days 70,90 and 110 of gestation to characterize more fully the specific differences in placental and fetal growith and development between the Meishän and Yorkshire breeds. At * slaughter, the length of each uterine horn was determined and fetal measurements were taken (weight and crown-rump length) and a section of each individual placenta and attached endometrium was collected for histological evaluation of the following: (1) number of villi per unit length of placenta (villar number), (2) length of villus attachment per unit length of placenta (villar depth), and (3) percentage of placenta occupied by blood vessels (placental vascular density). Each placenta was then weighed and its length determined as well as the length of its implantation site in 

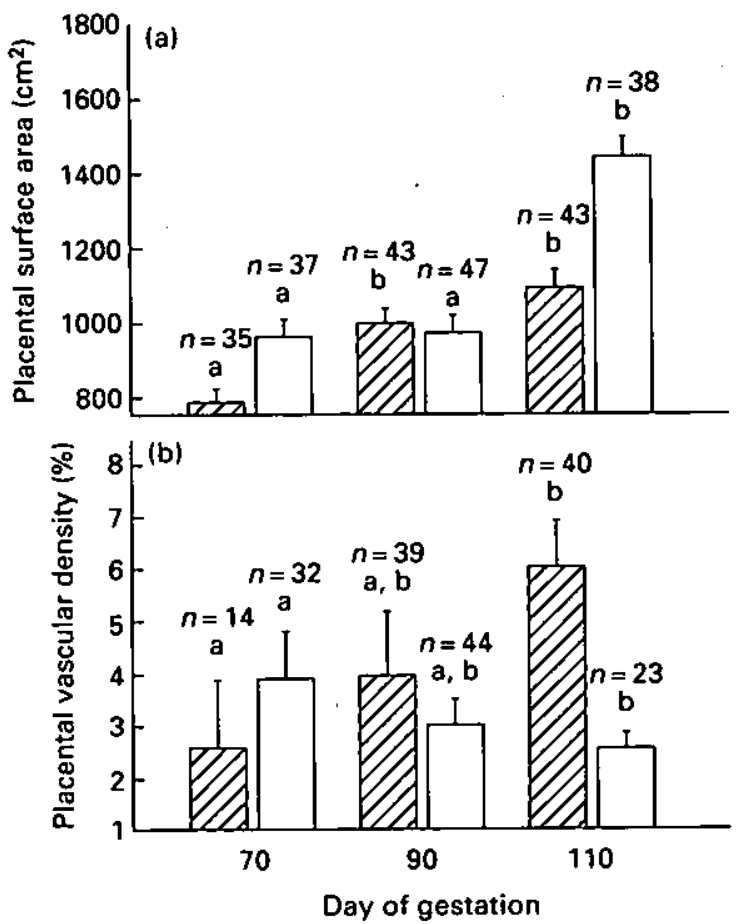

Fig. 6. Surface area (a) and associated blood vessel density (b) of placentae of Meishan ( $\square$ ) and $(\square)$ Yorkshire pigs on days 70,90 and 110 of gestation. ${ }^{a, b}$ Within a breed type, means \pm SEM with different superscripts are significantly different $(P<0.05)$.

the uterus. In addition, each placenta was cut along the anti-mesometrial border so that it could be spread out on a flat surface and traced with a planimeter to determine its surface area.

There was no effect of uterine position in which a conceptus resided (i.e. tip, middle or base) or the number of conceptuses in a horn on any fetal or placental measurement. In addition, no effect of breed or day was observed on total uterine length; however, conceptuses in Meishan uteri occupied a smaller $(P<0.01)$ length of uterine horn than conceptuses in Yorkshire uteri (Fig. 3). Furthermore, implantation site length of conceptuses in both Meishan and Yorkshire uteri increased by about $20 \%$ from day 70 to day 110 of gestation. The decreased implantation site length of conceptuses. in Meishan versus Yorkshire uteri is reflected by the fact that both Yorkshire and Meishan fetuses grew more slowly in a Meishan than in a Yorkshire uterus from day 70 to day 110 (Fig. 4a,b). The number of chorionic villi per unit length of placenta was similar for Meishan and Yorkshire placentae. Thus, the length of villus attachment per unit length placental-endometrial interface reflects the relative depth to which chorionic villi extended into the endometrial folds (Fig. 5). As depicted, villi length increased progressively from day 70 to day 110 of gestation and was similar across uterine and fetal breeds.

However, the pattern of placental growth differed markedly between Meishan and Yorkshire conceptuses. Surface area of Yorkshire placentae remained relatively constant from day 70 to day 90 , before increasing $(P<0.001)$ markedly by day 110 (Fig. 6a), while exhibiting a progressive decline in placental vascular density (Fig. 6b). In contrast, the surface area of Meishan placentae increased only moderately from day 70 to day 90 , and failed to exhibit any further increase from day 90 to day 110 (Fig. 6a). Throughout this period, and in contrast to the Yorkshire placenta, the Meishan placenta showed a marked increase $(P<0.01)$ in vascular density (Fig. 6 b). The fetal weight: placental weight ratio of these conceptuses on day 110 was markedly higher $(P<0.01)$ for Meishan than for Yorkshire 
conceptuses gestated in Meishan $(6.07 \pm 0.35$ and $4.65 \pm 0.20)$ or Yorkshire $(5.08 \pm 0.17$ and $4.35 \pm 0.15)$ uteri, due predominantly to differences in placental size.

\section{Conclusion}

The numbers of blood vessels per unit placental area at the uterine interface will determine in large part the capacity for nutrient exchange between the fetus and dam. As a result of this progressively increasing efficiency of nutrient and oxygen extraction per unit area of placenta, the Meishan conceptus can support the growth and development of a viable fetus with a much smaller placenta than is found in US pig breeds. Since the real limitation to litter size is the available space in the uterus, conceptuses that occupy less uterine space would result in larger litters.

The Meishan pig, therefore, has two separate yet complimentary strategies for increasing litter size. Firstly, the Meishan conceptus develops from fewer cells in the early stages of development than do similar stage conceptuses of US or European pig breeds, resulting in reduced oestradiol production. This reduced oestradiol production by the preimplantation Meishan conceptus results in less marked changes in the composition of uterine histotroph, allowing more conceptuses to survive beyond day 18 of gestation than for US or European pig breeds. Secondly, the Meishan conceptus develops a smaller, more vascular placenta than that found in US or European pig breeds. Furthermore, owing to their smaller size, more Meishan conceptuses are accommodated by the uterus after day 30 of gestation, when uterine size becomes limiting. Therefore, each Meishan placenta requires less endometrial space for nutrient exchange throughout late pregnancy when fetal demands are increasing, leading to the potential for larger litters.

\section{References}

Baur R (1977) Morphometry of the placenta exchange area Adoances in Anatomy, Embryology and Cell Biology 53 1-65

Bazer FW, Thateher WW, Martinal-Botte F and Terqui M (1988) Sexual maturation and morphological development of the reproductive tract in Large White and prolific Chinese Meishan pigs Journal of Reproduction and Fertility 83 723-728

Brambell CE (1933) Allantochorionic differentiation of pig American Journal of Anatomy 52 397-459

Chastant S, Monget P and Terqui M (1994) Localization and quantitation of insulin-like growth factor-I (IGF-I) and IGF-II/Mannase-6-Phosphate (IGF-II/M6P) receptors in pig embryos during early pregnancy Biology of Reproduction 51 588-596

Christenson RK (1993) Ovulation rate and embryonic survival in Chinese Meishan and white crossbred pigs Joumal of Animal Science 71 3060-3066

Christenson RK, Leymaster KA and Young LD (1987) Justification of unilateral hysterectomy-ovariectomy as a model to evaluate uterine capacity in swine Journal of Animal Science $65738-744$

Conley A], Christenson RK, Ford SP, Geisert RD and Mason JI (1992) Steroidogenic enzyme expression in porcine conceptuses during and after elongation Endocrinology 131 896-902

Conley AJ, Christenson LK, Ford SP and Christenson RK (1994) Immunocytochemical localization of cytochrome P450 $17 \alpha$-hydroxylase and aromatase in embryonic cell layers of elongating porcine blastocysts Endocrinology 135 2248-2254

Corps AN, Brigstock DR, Littiewood CJ and Brown KD (1990) Receptors for epidermal growth factor and insulin-like growth factor-I on preimplantation trophectoderm of the pig Development 110 221-227

Dantzer V (1985) Electron microscopy of the initial stages of placentation in the pig Anatomy and Enbryology 172 281-293

Dhindsa DS, Dziuk PJ and Norton HW (1967) Time of transuterine migration and distribution of embryos in the pig Anatomical Record 159 325-330

Dziuk PJ (1968) Effect of number of embryos and utcrine space on embryo survival in the pig Journal of Animal Science 27 673-676

Dziuk PJ (1985) Effects of migration, distribution and spacing of pig embryos on pregnancy and fetal survival joumal of Reproduction and Fertility Supplement 33 57-63

Dziuk PJ (1987) Embryonic loss in the pig: an enigma. In Australasia Pig Science Association Committee pp 28-39 Manipulating Pig Production, Australasia Pig Science Association, Melbourne, Australia

Ferrell Cl. (1991a) Maternal and fetal influences on uterine and conceptus development in the cow: 1 . Growth of tissues of the gravid uterus Journal of Animal Science 69 1945-1953

Ferrell CL (1991b) Maternal and fetal influences on uterine and conceptus development in the cow: II. Blood flow and nutrient flux Jounal of Animal Science 69 1954-1965

Flint APF (1981) A unifying hypothesis for the control of blastocyst growth based on observations of the pig journal of Reproduction and Fertility Supplement 29 215-227

Ford SP (1995) Control of blood flow to the gravid uterus of domestic livestock species Journal of Animal Science 73 $1852-1860$

Ford SP and Youngs CR (1993) Early embryonic development in prolific Meishan pigs Journal of Reproduction and Fertility Supplement 48 271-278 
Ford SP, Christenson RK and Ford J] (1982) Uterine blood flow and uterine arterial, venous and luminal concentrations of oestrogens on Days 11, 13 and 15 after oestrus in pregnant and non-pregnant sows Jourmal of Reproduction and Feritity $64185-190$

Friess AC, Sinowatz F, Skolek-Winnisch R and Träutner W (1980) The placenta of the pig Anatomy and Embryology 158 179-191

Gadsby JE, Heap RB and Burton RD (1980) Oestrogen production by blastocysts and early embryonic tissue of various species Journal of Reproduction and Fertility $60409-417$

Galvin JM, Wilmut I, Day BN, Ritchie $M$, Thomsen $M$ and Haley CS (1993) Reproductive performance in relation to uterine and embryonic traits during early gestation in Meishan, Large White and crossbred sows foumal of Reproduction and Fertility 98 277-384

Geisert RD, Brookbank JW, Roberts RM and Bazer FW (1982a) Establishment of pregrancy in the pig: II. Cellular remodeling of the porcine blastocyst during elongation on day 12 of pregnancy Biology of Reproduction 27 941-955

Geisert RD, Renegar RH, Thatcher WW, Roberts RM and Bazer FW (1982b) Establishment of pregnancy in the pig: I. Interrelationship between preimplantation development of the pig blastocyst and uterine endometrial secretions Biology of Reproduction 27 925-939

Geisert RD, Morgan GL, Zavy MT, Blair RM, Gries LK, Cox A and Yellin T (1991) Effect of asynchronous transfer and oestrogen administration on survival and development of porcine embryos Journal of Reproduction and Fertility 93 $475-481$

Grosser O (1909) Vergleichende Anatomie und Entwicklungsgeschichte der Eihäute und der Placenta Braumüller, Lecipzig

Haley CS and Lee GJ (1993) Genetic basis of prolificacy in Meishan pigs Jowrnal of Reproduction and Fertility Supplement 48 247-259

Hammond J (1914) On some factors controlling fertility in domestic animals journal of Agriculhural Science 6 263-274

Hunter GL (1958) The maternal influence on size in sheep Joumal of Agricultural Science (Cambridge) 48 36-60

Jin RB, Cui HM and Mao JD (1992) Reproductive characteristics of Taihu pigs Pig Netus and Information $1399 \mathrm{~N}-102 \mathrm{~N}$

Knight JW, Bazer FW, Thatcher WW, Franke DE and Wallace HD (1977) Conceptus development in intact and unilaterally hysterectomized ovariectomized gilts: internelations among hormonal states, placental development, fetal fluids and fetal growt Journal of Aninal Science 44 620-637

Ko Y, Choi I, Green ML, Simmen FA and Simmen RCM (1994) Transient expression of the cytochrome $\mathrm{P450}$ aromatase gene in elongating porcine blastocysts is correlated with uterine insulin-like growth factor levels during periimplantation development Molecular Reproduction and Development 37 1-11

Lee GJ, Ritchie $M$, Thomson $M$, Macdonald AA, Blasco A, Santacreu MA, Argente MJ and Haley CS (1995) Uterine capacity and prenatal survival in Meishan and Large White pigs Animal Science $60471-479$

Lewis AM, Kaye PL, Lising $R$ and Cameron RDA (1992) Stimulation of protein synthesis and expansion of pig blastocysts by insulin in vitro. Reproduction Fertility and Development 4 119-123

Morgan GL, Geisert RD, Zavy MT, Shawley RV and Fazleabas AT (1987) Development of pig blastocysts in a uterine environment advanced by exogenous oestrogen Joumal of Reproduction and Fertility 80 125-131
Paria BC and Dey SK (1990) Preimplantation embryo development in vitro: cooperative interactions among embryos and role of growth factors Proceedings of the National Academy of Sciences USA 87 4756-4760

Pollard JW (1990) Regulation of polypeptide growth factor synthesis and growth-related gene expression in the rat and mouse uterus before and after implantation journal of Reproduction and Fertility 88 721-731

Pope WF (1994) Embryonic mortality in swine. In Embryonic Mortality in Domestic Animals Pp 53-77 Eds MT Zavy and RD Geisert. CRC Press Inc, Boca Raton

Pope CE, Christenson RK, Zimmerman-Pope VA and Day BN (1972) Effect of number of embryos on embryonic survival in recipient gilts Journal of Animal Science 35 805-808

Pope WF, Xie S, Broermann DM and Nephew KP (1990) Causes and consequences of early embryonic diversity in pigs Joumal of Reproduction and Fertility Supplement 40 251-260

Pork Facts (1993) National Pork Producers Council p 6 Ed. C Miller. National Pork Producers Association Des Moines, IA

Pusateri AE, Rothschild MF, Wamer CM and Ford SP (1990) Changes in morphology, cell number, cell size and cellular estrogen content of individual littermate pig conceptuses on days 9 to 13 of gestation Journal of Animal Science 68 3727-3735

Reynolds LP and Redmer DA (1995) Utero-placental development and placental function Joumal of Animal Science 73 1839-1851

Reynolds LP, Fond SP and Ferrell CL (1985) Blood flow and steroid and nutrient uptake of the gravid uterus and fetus of sows Journal of Animal Science 61 968-974

Rivera RM, Christenson LK, Youngs CR and Ford SP (1994) Competitive survival growth rate and estrogen secretory activity of Meishan and Yorkshire fetuses Journal of Animal Science 72 (Supplement 1) 78 (Abstract)

Rivera RM, Youngs CR and Ford SP (1996) A comparison of the number of inner cell mass and trophectoderm cells of preimplantation Meishan and Yorkshire pig embryos at similar developmental stages Journal of Reproduction and Fertility 106 111-116

Roberts RM and Bazer FW (1988) The functions of uterine secretions Joumal of Reproduction and Ferlility 82 875-892

Scofield AM (1972) Embryonic mortality. In Pig Production pp 367-383 Ed. CJA Cole. Butterworths, London

Simmen FA and Simmen RCM (1991) Peptide growth factors and proto-oncogenes in mammalian conceptus development Biology of Reproduction 44 1-5

Simmen RCM, Green ML and Simmen FA (1995) IGF system in peri-implantation uterus and embryonic development. In Molecular and Cellular Aspects of Peri-implantation Processes pp 185-204 Ed. SK Dey. Serono Symposia USA, SpringerVerlag, New York

Stroband HWJ and Van der Lende T (1990) Embryonic and uterine development during early pregnancy in pigs Joumal of Reproduction and Fertility Supplement 40 261-277

Van der Meulen J, te Kronnie G, van Deursen $\mathbf{R}$ and Greelan J (1989) Aromatase activity in individual day-11 pig blastocysts Journal of Reproduction and Fertility 87 783-788

Venge $O(1950)$ The maternal influence on birth weight in rabbits Acta Zoologica 31 1-147

Warwick BL (1928) Prenatal growth of swine Journal of Morphology and Physiology 46 59-84

Wilson ME and Ford SP (1997) Differences in trophectoderm mitotic rate and $P 45017 \alpha$-hydroxylase expression 
between late preimplantation Meishan and Yorkshire conceptuses Biology of Reproduction 56 380-385

Wilson ME, Kaminski MA, Conley AJ and Ford SP (1995)

Development differences between. Meishan and Yorkshire preimplantation conceptuses Biology of Reproduction 52 (Supplement 1) 178 (Abstract)
Youngs CR, Christenson LK and Ford SP (1994) Investigations into the control of litter size in swine: III. A reciprocal embryo transfer study of early conceptus development journal of Animal Science 72 725-731 